\title{
Antarctic krill meal as an alternative protein source in pet foods evaluated in mink (Neovison vison). II. Growth
}

This article was published in the following Dove Press journal:

Open Access Animal Physiology

10 February 2015

Number of times this article has been viewed

\section{Åshild Krogdahl' \\ $\varnothing y s t e i n$ Ahlstrom ${ }^{2}$ \\ Lena Burri ${ }^{3}$ \\ Sigve Nordrum ${ }^{3}$ \\ Laurie C Dolan ${ }^{4}$ \\ Anne Marie Bakke' \\ Michael H Penn'}

'School of Veterinary Medicine, Norwegian University of Life Sciences, Oslo, Norway; ${ }^{2}$ Department of Animal and Aquacultural Sciences, Norwegian University of Life Sciences, Ås, Norway; ${ }^{3}$ Aker BioMarine Antarctic AS, Oslo, Norway; ${ }^{4}$ Burdock Group Consultants, Orlando, FL, USA
Correspondence: Åshild Krogdahl Norwegian University of Life Sciences, School of Veterinary Medicine, Department of Basic Sciences and Aquatic Medicine, PO Box 8I46, Dept NO-0033, Oslo, Norway Email ashild.krogdahl@nvh.no
Background: Antarctic krill meal has potential for use in pet food as a source of protein and lipids. An experiment was conducted in growing male and female mink to evaluate the safety of Antarctic krill meal as an ingredient for pet food.

Materials and methods: In the first growth period, the levels of krill were $0 \%, 8 \%, 17 \%$, and $33 \%$ of dry matter. The levels were slightly less in the second growth period $(0 \%, 8 \%, 16 \%$, and $32 \%$ of dry matter). The four diets used were labeled K0, K8, K17, and K33 for both growth periods. The experiments included assessments of growth, hematology, clinical chemistry, tissue histology, liver and kidney mineral concentrations, and bone fluoride accumulation.

Results: Mink receiving Antarctic krill meal grew at the same rate as controls, suggesting that protein and energy values of the krill meal were comparable to the control fishmeal. Relative organ weights of animals were the same for the K0, K8, and K17 groups, whereas K33 animals showed higher values for weights of the stomach and rectum. Hematological, clinical chemistry, and morphological analyses did not differ between animals fed $\mathrm{K} 0$ and $\mathrm{K} 8$ diets. Animals in the K17 and K33 groups showed some histological changes in the liver and kidney, and a few alterations in some clinical chemistry and hematology values related to nutrient intake or metabolism. Joint/bone deformities were observed in K33 mink.

Conclusion: Antarctic krill meal has a similar nutritional value as good-quality fishmeal and produces no adverse effects in growing mink at levels up to $8 \%$ of dry matter. The results suggest that Antarctic krill meal can be safely included in pet food for growing animals.

Keywords: Antarctic krill meal, protein source, growth, mink

\section{Introduction}

Antarctic krill (Euphausia superba) is receiving increased attention as a marine protein and lipid source for animals and man. Antarctic krill is an organism rich in the omega-3 ( $\omega-3)$ fatty acids eicosapentaenoic acid (20:5n-3) and docosahexaenoic acid (22:6n-3), ${ }^{1}$ which have several reported benefits for human health. ${ }^{2}$ In addition, the protein quality is comparable to that of good fishmeal. ${ }^{3}$ Krill was examined as a nutrient source for fish feeds in the late 1970 s and early $1980 \mathrm{~s},{ }^{4}$ but its use has been limited by challenges in processing. ${ }^{5}$ The potential for use of krill as a feed ingredient for fish and other monogastric animals has recently been reconsidered because of advances in processing technology and limitations in the supply of fishmeal. Antarctic krill meal is expected to be a healthy feed ingredient for pets, providing beneficial protein and fatty acids.

A major impediment to the high dietary inclusion of krill is its naturally high fluorine content, which originates from the exoskeleton. The current European Union 
(EU) limits on fluorine in animal feeds vary with species and life stage ${ }^{6,7}$ For nonruminant mammals, the general current limit is $150 \mathrm{mg} / \mathrm{kg}$ in complete feeds. For feed ingredients derived from marine crustaceans, the limit is $3,000 \mathrm{mg} / \mathrm{kg}$. Fluorine in whole Antarctic krill can vary from $1,000 \mathrm{mg} / \mathrm{kg}^{8,9}$ to $2,400 \mathrm{mg} / \mathrm{kg}$ (dry weight). ${ }^{10}$ The United States Department of Agriculture has not established a maximum recommended daily intake of fluorine. For adult humans, the US Institute of Medicine has set a tolerable upper intake level of $10 \mathrm{mg} /$ day. ${ }^{11}$ Fluorine content of krill can be reduced by separating the exoskeleton from the muscle fraction, ${ }^{12}$ although some fluorine may leak from the exoskeleton to the muscle during storage. ${ }^{13,14}$ A partial deshelling of the krill meal will also reduce the level of chitin, a long chain, nondigestible polymer of $\mathrm{N}$-acetyl-glucosamine that exhibits properties similar to dietary fiber. ${ }^{15}$ Another factor that may limit the use of krill in animal feeds is the naturally high copper content, which ranges from $13 \mathrm{mg} / \mathrm{kg}-81 \mathrm{mg} / \mathrm{kg}$ in whole krill. ${ }^{16-18}$ In contrast to vertebrates (which use hemoglobin for oxygen and carbon dioxide transport), crustaceans such as krill use hemocyanin that utilizes copper as the prosthetic group, ${ }^{19}$ which results in high copper levels in krill. ${ }^{16}$ The EU currently allows up to $25 \mathrm{mg} / \mathrm{kg}$ copper in complete feedstuffs. ${ }^{20}$

Few studies have been performed to investigate Antarctic krill meal inclusion in feeds for terrestrial mammals. Studies performed over 30 years ago indicate that use of up to $25 \%$ "raw krill" in feed is well tolerated by mink and produces beneficial effects on fur quality. ${ }^{21,22}$ The need for thorough studies is therefore urgent to assess nutritional value and possible health implications. Mink is considered a good model for evaluation of nutritional and toxicological aspects of feed ingredients for other mammals, including dogs, cats, and foxes. ${ }^{23-26}$ Efficient and accurate standard procedures have been developed for nutritional studies. The current work used mink as a model for dogs and cats with the aim to characterize nutritional and safety aspects of Antarctic krill meal. In the feeding experiment, the krill meal partially replaced fishmeal and the nutritional, physiological, and histopathological effects were assessed.

\section{Materials and methods}

\section{Test substance and diet formulation}

The live animal work of the project and evaluation of nutritional characteristics of the diets were conducted at the Norwegian University of Life Sciences' (NMBU's) Department of Animal and Aquacultural Sciences, Ås, Norway, where feeds were also produced. The farm is under the supervision of the Norwegian Research Authority and Norwegian protocols of ethical standards concerning experiments involving animals were followed. Evaluation of the health-related effects of the diets was conducted at NMBU's School of Veterinary Medicine, Department of Basic Sciences and Aquatic Medicine, Oslo, Norway. The Antarctic krill meal product used in the experiment was Antarctic krill meal produced on June 1, 2010 and supplied by Aker BioMarine AS (Oslo, Norway). The control fishmeal was NorSeaMink meal (Norsildmel AS, Fyllingsdalen, Norway).

Antarctic krill meal was tested at four levels, including a control diet containing no Antarctic krill meal. Diet compositions are given in Table 1 . The diets were formulated to have metabolizable energy (ME) content of $5 \mathrm{MJ} / \mathrm{kg}$ on a wet weight basis, and the percentages of ME from protein, lipid, and carbohydrates of $40 \%, 45 \%$, and $15 \%$, respectively. In the diets with Antarctic krill, the krill meal replaced a portion of the protein coming from fishmeal in the control diet. Protein from Antarctic krill meal accounted for $0 \%, 15 \%, 30 \%$, and $60 \%$ of the protein in the four experimental diets and $0 \%$, $9 \%, 17 \%$, and $35 \%$ of dry matter (DM) of the diets in the first feeding period from June 23-August 1. In the second feeding period, from August 2-October 3, the energy density of the feed was planned to account for approximately $6.5 \mathrm{MJ} / \mathrm{kg}$ on a wet weight basis by including higher amounts of lard and soybean oil. The contribution of the krill to DM to each of the four diets used in the second period was approximately $0 \%, 8 \%, 16 \%$, and $32 \%$. Throughout this document, the respective diets are referred to as $\mathrm{K} 0, \mathrm{~K} 8, \mathrm{~K} 17$, and $\mathrm{K} 33$, although there were slight differences in the first and second feeding periods. The inclusion of protein sources other than krill was similar for the four diets, and krill protein as part of total protein did not change. The diets were produced weekly. The daily rations for the first 3 days were stored at $4^{\circ} \mathrm{C}$ until feeding, while the rations for the last 4 days were stored frozen $\left(-20^{\circ} \mathrm{C}\right)$ and thawed the day before use. The animals were fed once daily and drinking water was given by a semiautomatic system (nipples). Daily feed consumption was recorded separately for each sex on a group basis.

\section{Animals and housing}

Sixty-four mink kits (black genotype, 52-53 days old, body weight [BW] range: $338 \mathrm{~g}-740 \mathrm{~g}$ ) were allocated into four groups of eight males and eight females per group. The kits were offspring of females involved in a preceding reproduction trial, which was reported in a separate paper. ${ }^{27}$ Two animals of the same sex were housed in each cage. The animals were kept in semioutdoor houses with natural daylight. Each pair of individuals was kept in a cage measuring $0.45 \mathrm{~m}$ in height $\times 0.27 \mathrm{~m}^{2}$ floor area. The cages were arranged in two rows and pairs belonging 
Table I Diet composition, chemical content, and energy of diets $(\mathrm{g} / \mathrm{kg})$

\begin{tabular}{|c|c|c|c|c|c|c|c|c|}
\hline \multirow[t]{2}{*}{ Date $^{a}$} & \multicolumn{2}{|l|}{ KO } & \multicolumn{2}{|l|}{ K8 } & \multicolumn{2}{|l|}{ KI7 } & \multicolumn{2}{|l|}{ K33 } \\
\hline & $6 / 23-8 / 1$ & $8 / 2-10 / 3$ & $6 / 23-8 / 1$ & $8 / 2-10 / 3$ & $6 / 23-8 / 1$ & $8 / 2-10 / 3$ & $6 / 23-8 / 1$ & $8 / 2-10 / 3$ \\
\hline \multicolumn{9}{|l|}{ Ingredient (g/kg) } \\
\hline Krill meal & - & - & 34.7 & 33.5 & 67.5 & 65.0 & $|3|$ & 126 \\
\hline Fishmeal & 153.2 & 148 & 117.5 & 113.5 & 80.5 & 77.5 & 12.8 & 12.0 \\
\hline Precooked carbohydrates & 139 & 134 & 139 & 134 & 136 & 131.5 & 127 & 123 \\
\hline Cod scraps & 139 & 134 & 139 & 134 & 135 & 130.5 & 126.5 & 122 \\
\hline Poultry by-products & 139 & 134 & 139 & 134 & 135 & 130.5 & 126.5 & 122 \\
\hline Lard (pig fat) & 13.9 & 35 & 13.9 & 35 & 13.5 & 35 & 12.6 & 35 \\
\hline Soybean oil & 13.9 & 25 & 13.9 & 25 & 13.5 & 25 & 12.6 & 25 \\
\hline Vitamin/mineral $\mathrm{mix}^{\mathrm{b}}$ & 2 & 2 & 2 & 2 & 2 & 2 & 2 & 2 \\
\hline Water & 400 & 388 & 401 & 389 & 417 & 403 & 449 & 433 \\
\hline Sum & 1,000 & 1,000 & 1,000 & 1,000 & 1,000 & 1,000 & 1,000 & 1,000 \\
\hline $\mathrm{DM}, \mathrm{g} / \mathrm{kg}$ & 370 & 391 & 384 & 384 & 321 & 371 & 362 & 357 \\
\hline \multicolumn{9}{|c|}{ Chemical content (kg DM)c } \\
\hline Crude protein & 441 & 414 & 438 & 411 & 424 & 420 & 434 & 406 \\
\hline Crude lipid & 173 & 230 & 172 & 234 & 165 & 235 & 174 & 232 \\
\hline Carbohydrates $^{d}$ & 272 & 266 & 286 & 259 & 305 & 248 & 295 & 269 \\
\hline Ash & 114 & 90 & 104 & 96 & 106 & 97 & 97 & 92 \\
\hline $\mathrm{ME}^{\mathrm{c}, \mathrm{e}}(\mathrm{MJ} / \mathrm{kg} \mathrm{DM})$ & 16.1 & 17.5 & 16.2 & 17.7 & 16.0 & 17.8 & 16.3 & 17.6 \\
\hline \multicolumn{9}{|l|}{ ME distribution ${ }^{c}$} \\
\hline Protein & 42 & 37 & 42 & 36 & 41 & 37 & 41 & 36 \\
\hline Lipid & 38 & 47 & 38 & 48 & 32 & 47 & 38 & 47 \\
\hline Carbohydrates & 20 & 16 & 20 & 16 & 27 & 16 & 21 & 17 \\
\hline \multicolumn{9}{|c|}{ Mineral content (mg/kg DM) } \\
\hline Copper & & 11.5 & & 15.6 & & 20.8 & & 31.3 \\
\hline Fluoride & & 73 & & 291 & & 419 & & 626 \\
\hline Arsenic & & 2.7 & & 2.7 & & 2.5 & & 1.8 \\
\hline Calcium & & 25,000 & & 29,170 & & 28,130 & & 26,040 \\
\hline
\end{tabular}

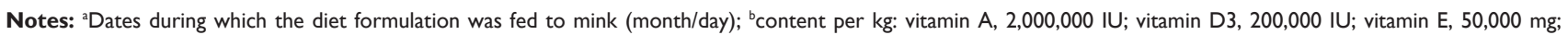
vitamin BI, 15,000 mg; vitamin B2, 3,000 mg; vitamin B6, 3,000 mg; vitamin BI2, $19.5 \mathrm{mg}$; Ca-D- pantothenic acid, 3,332 mg; niacin, 5,005 mg; biotin, $30 \mathrm{mg}$; folic acid, $301 \mathrm{mg}$; ferrous sulfate, $610 \mathrm{mg}$; ferrous fumarate, 15,280 mg; Fe (chelated), 4,II $0 \mathrm{mg}$; copper sulfate, I,250 mg; manganese oxide, 7,502; zinc oxide, 9,998 mg; Ca iodinate, $63.5 \mathrm{mg}$; Na selenite, $99.9 \mathrm{mg}$; cobalt carbonate, $60 \mathrm{mg}$; chemical content and energy values are data from one sample per diet from the period 6/23-8/I and two samples per

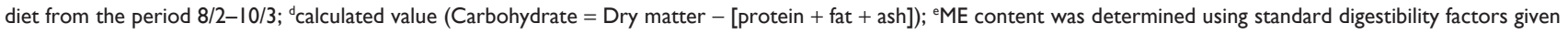
by the Norwegian Fur Breeders' Association of $82 \%, 90 \%$, and $68 \%$ for protein, fat, and carbohydrates, respectively, and the ME content of $18.8 \mathrm{~kJ} / \mathrm{g}$, $39.8 \mathrm{~kJ} / \mathrm{g}$, and $17.6 \mathrm{~kJ} / \mathrm{g}$ of digestible protein, fat, and carbohydrates, respectively (Data from Hansen et al. ${ }^{28}$ ).

Abbreviations: DM, dry matter; ME, metabolizable energy; MJ, megajoules; IU, international units.

to the same group were placed in cages side by side, with an empty cage between different groups. The kits were continued in the present growth trial in the same groups as they were in the previous trial until weaning (control or low, mid, or high dose). The animals were weighed on day 0 (June 23), day 30 (July 22), day 57 (August 18), day 83 (September 14), and on the last day of the 102-day experiment (October 3).

\section{Sampling and sample treatment}

At the end of the 15-week growth trial (October 5-7), animals were euthanized, necropsied, and sampled for laboratory analyses. Animals were rendered unconscious by electric shock using a Euthanatos 2 (Lima A/S, Sandnes, Norway) and immediately euthanized by cervical dislocation. Blood samples were taken after euthanasia by cardiac puncture. Pelts were removed and animals dissected. Organs were examined grossly and weighed. Tissue samples for histology were taken from the stomach, jejunum, colon, rectum, liver, kidney, spleen, adrenal glands, and heart, fixed in neutral buffered formalin $(4 \%$ formaldehyde; $\mathrm{pH}$ 7.4), and processed using routine methods (NMBU School of Veterinary Medicine). Tissue sections were stained with hematoxylin and eosin. Liver tissue was stained with periodic acid-Schiff (PAS) stain to identify glycogen. All collected organs from the control and high dosage animal groups; and liver, spleen, and kidney samples from all other groups were evaluated histologically. The blinded samples were evaluated under a light microscope in random order. For bone fluoride and kidney and liver trace metal analyses, samples from two animals in the same group were pooled (if possible). Blood and plasma samples were analyzed at the NMBU School of Veterinary Medicine for complete blood cell count and plasma biochemistry profiles using certified assays. The complete blood count included red blood cell count (RBC), hemoglobin concentration (HGB), hematocrit 
(HCT), mean cell volume (MCV), mean cell HGB (MCHC), red blood cell distribution width (RDW), platelet count, and total and differential white blood cell count (WBC).

\section{Chemical analyses}

Diets were analyzed for dry matter (heating at $105^{\circ} \mathrm{C}$ for 16-18 hours), ash (combustion at $550^{\circ} \mathrm{C}$ to constant weight), crude protein as nitrogen $\times 6.25$ (by the semimicro-Kjeldahl method; Kjeltec Auto System, Tecator AB, Hognas, Sweden), and lipid (diethyl ether extraction in a Fosstec analyzer [Tecator ${ }^{\mathrm{TM}}$ ] after $\mathrm{HCl}$ hydrolysis). Carbohydrates were calculated by difference:

$$
[\text { Carbohydrate }=\text { Dry matter }-(\text { protein }+ \text { fat }+ \text { ash })]
$$

Diets were analyzed for fluorine, copper, arsenic, and calcium. Liver and kidney tissue homogenates were analyzed for copper, cadmium, arsenic, and zinc. Dried, defatted bone (left femur) was analyzed for fluoride. The analyses were performed at Eurofins Food and Agro Testing, Kambo, Norway, using standard procedures. All minerals except fluorine were analyzed by simultaneous inductively coupled plasma spectroscopy (ICP) on a Vista Pro CCD (NMKL 161). An ion-selective electrode detector was used for the fluorine analysis.

\section{Statistics}

Means and standard deviations were calculated for all quantitative data. Data within groups were evaluated for homogeneity of variance and normality by Bartlett's test. Where Bartlett's test indicated homogeneous variances, treated and control groups were compared using a one-way analysis of variance (ANOVA), with the exception of BW data, which were compared using a two-way repeated measures ANOVA. Data for each sex were analyzed separately. When the results of ANOVA were statistically significant, a Tukey's test for multiple comparisons was performed to compare results of all groups. When variances were significantly different by Bartlett's test, groups were compared using a nonparametric method (Kruskal-Wallis nonparametric ANOVA). When the results of the nonparametric ANOVA were statistically significant, all groups were compared using Dunn's test (Prism 5.02, GraphPad Software, Inc., La Jolla, CA, USA). The critical value for significance of all comparisons was $P<0.05$.

\section{Results}

\section{Diet characteristics}

Chemical composition and ME content of the diets are shown in Table 1. Nutrient contents and ME distribution between protein, fat, and carbohydrates were similar in the four experimental diets within the two experimental periods. Diets containing Antarctic krill meal contained higher amounts of copper and fluorine and lower amounts of arsenic than did the control diet. Fluorine content was 8.5 times higher in the $\mathrm{K} 33$ diet than in the $\mathrm{K} 0$ diet. Calcium levels were similar in all diets.

\section{Growth and organ weights}

All animals appeared healthy and showed good appetite throughout the experiment, except for one male that was fed the K33 diet - it died on July 14 because of an infection with Streptococcus canis in a wound on one hind leg. In addition, one male in group $\mathrm{K} 0$ died on September 5 of an unknown cause. The K33 kit that died early was replaced by a sibling, whereas the K0 kit was not replaced. For each sex, feed consumption (measured as g/day for the whole group) was similar among the groups. As expected, feed intake was higher in males (298-310 g/day) than females (210-225 g/day), regardless of krill meal inclusion. There was no effect of krill meal on BWs of male or female mink compared to controls (Figure 1). The only statistically significant differences between BWs were for males in the $\mathrm{K} 8$ group versus males in the $\mathrm{K} 17$ or K33 groups on day $102(P<0.05)$ (Figure 1).

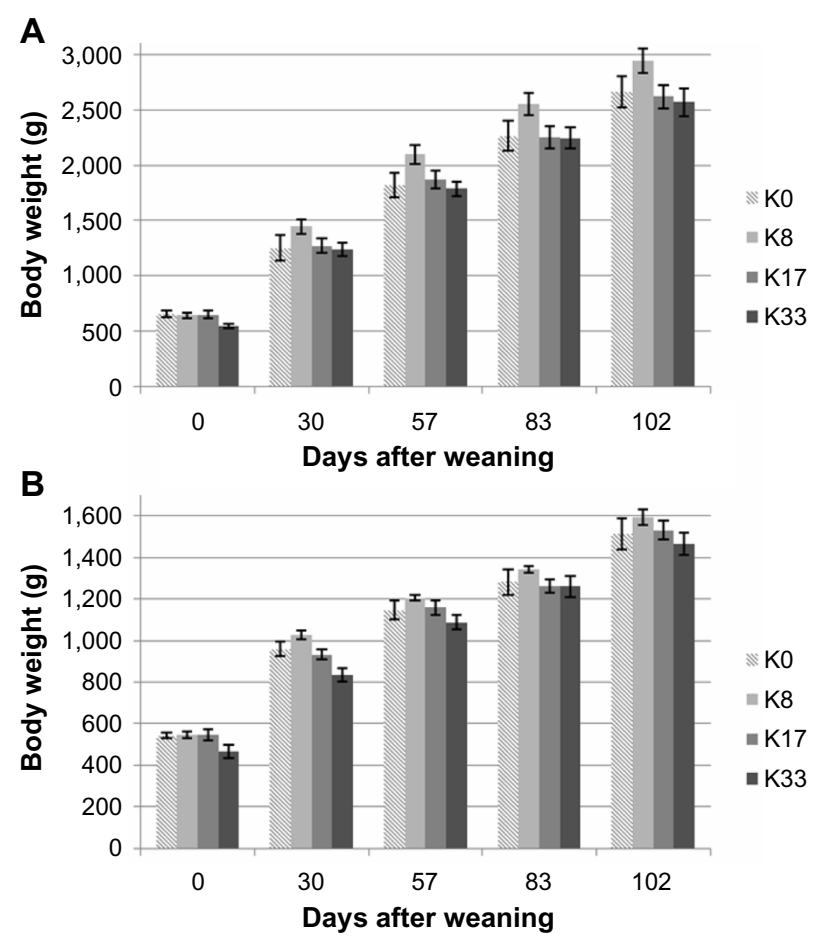

Figure I Body weights (g).

Notes: (A) Male and (B) female mink throughout the experiment as a function of the inclusion of Antarctic krill meal; data are presented as the mean \pm standard error. 
Relative weights of the stomach (both sexes) and rectum (females only) increased with increasing dietary inclusion of krill (Table 2). The elevations were, however, small and statistically significant only for the K33 animals. The relative heart weight of the $\mathrm{K} 33$ females was higher than that of the K8 females $(P<0.05)$, but this was not significantly different from controls (Table 2). The relative weight of the liver decreased slightly with increasing krill level; however, the decrease was not statistically significant. No relationship was observed between dietary krill level and the relative weights of the kidneys, spleen, brain, adrenals, or gonads (Table 2).

\section{Organ structure}

There was no clear relationship between dietary krill level and gross pathology, with the exception of joint/bone deformities in the K33 group (Table 3). The histological examination of the liver indicated reduced liver glycogen with increasing dietary Antarctic krill meal (Table 4) and staining (PAS) confirmed this finding (Figures 2 and 3). Reduced liver glycogen was found in males and females in the K17 and K33 groups. Glycogen staining had a distinct centrilobular distribution, but it also showed higher glycogen deposition around vessels and at the periphery of the liver lobe. Small focal to multifocal inflammatory lesions were also noted in the liver. The frequency of the observation (Table 5) in males and females of the K17 and K33 groups suggests a possible relationship with the dietary krill meal level. Lipoid-like vacuolization was noted in two to three animals in the control, low, and mid-dosage groups, and seven animals in the high dosage group. Crystals (basophilic crystalline material) were observed within tubules in the kidneys of controls and animals ingesting krill meal (Figure 4); however, they appeared more frequently in males and females in the K17 and K33 groups and males in the $\mathrm{K} 8$ group (Table 6). There were no pathological changes associated with the crystallization, including inflammation. One male in the K8 group and three males in the K17 group exhibited "moderate" active lymphoid follicles in the spleen and seven animals from the K33 group (six males and one female) exhibited "moderate to marked" active lymphoid follicles in the spleen (Figure 5). Splenic nodules were observed during necropsy in two of the K33 males that exhibited active lymphoid follicles. There were no test material-related findings in the histopathology of the gastrointestinal tract, adrenal gland, or heart.

\section{Bone structure and fluoride concentration}

Bone fluoride increased with increasing dietary Antarctic krill meal inclusion (Figure 6). The effect was consistent between males and females and fluoride accumulated to high levels in the K33 group. During preparation of the femur samples for fluoride analysis, several deformities were noted in the animals in the K33 group: 7/8 males and 1/8 females had deformities of the femoral neck or head (Figure 7). No bone deformities were noted in any of the other groups.

\section{Liver and kidney metal concentrations}

Liver tissue concentrations of copper, cadmium, arsenic, and zinc are shown in Table 7. There was a positive relationship between krill level and copper and zinc concentrations in the livers of K33 males. Liver cadmium levels increased with increasing dietary krill, with values for $\mathrm{K} 33$ males and females significantly different from their respective controls. Arsenic decreased with increasing inclusion of krill meal, but

Table 2 Organ relative weights ( $\mathrm{g} / \mathrm{l} 00 \mathrm{~g}$ body weight) of mink fed the experimental diets

\begin{tabular}{|c|c|c|c|c|c|c|c|c|c|c|c|}
\hline & $\mathbf{n}$ & Stomach & Intestine & Rectum & Liver & Kidney & Spleen & Heart & Brain & Adrenal & Gonad \\
\hline \multicolumn{12}{|l|}{ Males } \\
\hline Ko & 7 & $0.44 \pm 0.09^{a}$ & $2.38 \pm 0.83$ & $0.18 \pm 0.04$ & $2.82 \pm 0.64$ & $0.55 \pm 0.17$ & $0.24 \pm 0.03$ & $0.57 \pm 0.13$ & $0.48 \pm 0.08$ & $0.005 \pm 0.001$ & $0.044 \pm 0.005$ \\
\hline K8 & 8 & $0.43 \pm 0.07^{\mathrm{a}}$ & $1.90 \pm 0.30$ & $0.15 \pm 0.02$ & $2.3 \mathrm{I} \pm 0.27$ & $0.48 \pm 0.11$ & $0.20 \pm 0.06$ & $0.53 \pm 0.08$ & $0.44 \pm 0.05$ & $0.005 \pm 0.001$ & $0.038 \pm 0.005$ \\
\hline $\mathrm{K} / 7$ & 8 & $0.46 \pm 0.06^{\mathrm{a}}$ & $2.03 \pm 0.21$ & $0.18 \pm 0.02$ & $2.37 \pm 0.26$ & $0.49 \pm 0.08$ & $0.18 \pm 0.03$ & $0.56 \pm 0.07$ & $0.47 \pm 0.06$ & $0.005 \pm 0.001$ & $0.042 \pm 0.010$ \\
\hline K33 & 8 & $0.55 \pm 0.05^{b}$ & $2.18 \pm 0.18$ & $0.19 \pm 0.02$ & $2.23 \pm 0.30$ & $0.46 \pm 0.05$ & $0.26 \pm 0.09$ & $0.57 \pm 0.06$ & $0.5 I \pm 0.06$ & $0.006 \pm 0.001$ & $0.046 \pm 0.008$ \\
\hline$P$-value & & 0.004 & 0.070 & 0.117 & 0.070 & 0.477 & 0.059 & 0.760 & 0.184 & 0.570 & 0.159 \\
\hline \multicolumn{12}{|c|}{ Females } \\
\hline KO & 8 & $0.47 \pm 0.04^{a}$ & $2.13 \pm 0.24$ & $0.17 \pm 0.0 \mathrm{I}^{\mathrm{a}}$ & $2.5 I \pm 0.19$ & $0.53 \pm 0.07$ & $0.23 \pm 0.05$ & $0.59 \pm 0.09^{\mathrm{a}}$ & $0.68 \pm 0.08$ & $0.006 \pm 0.001$ & $0.006 \pm 0.002$ \\
\hline K8 & 8 & $0.5 \mathrm{I} \pm 0.03^{\mathrm{a}}$ & $2.20 \pm 0.24$ & $0.18 \pm 0.03^{\mathrm{a}, \mathrm{b}}$ & $2.52 \pm 0.36$ & $0.5 I \pm 0.05$ & $0.27 \pm 0.13$ & $0.56 \pm 0.06^{\mathrm{a}, \mathrm{b}}$ & $0.69 \pm 0.08$ & $0.007 \pm 0.002$ & $0.006 \pm 0.002$ \\
\hline $\mathrm{K} 17$ & 8 & $0.5 \mathrm{I} \pm 0.05^{\mathrm{a}}$ & $2.22 \pm 0.13$ & $0.19 \pm 0.02^{\mathrm{a}, \mathrm{b}}$ & $2.36 \pm 0.26$ & $0.49 \pm 0.05$ & $0.22 \pm 0.03$ & $0.60 \pm 0.06^{\mathrm{a}}$ & $0.69 \pm 0.07$ & $0.006 \pm 0.001$ & $0.006 \pm 0.002$ \\
\hline K33 & 8 & $0.61 \pm 0.08^{b}$ & $2.36 \pm 0.21$ & $0.20 \pm 0.02^{\mathrm{b}}$ & $2.32 \pm 0.19$ & $0.49 \pm 0.08$ & $0.24 \pm 0.05$ & $0.68 \pm 0.10^{a, c}$ & $0.72 \pm 0.08$ & $0.006 \pm 0.001$ & $0.007 \pm 0.002$ \\
\hline$P$-value & & $<0.0001$ & 0.210 & 0.023 & 0.311 & 0.613 & 0.887 & 0.020 & 0.743 & 0.318 & 0.628 \\
\hline
\end{tabular}

Notes: Values with different superscripts (letters) are significantly different from each other $(P<0.05)$. $\mathrm{n}=6$ for K0 male gonad weight (no gonad weight was taken for one animal that had only one gonad).

Abbreviation: $\mathrm{n}$, number of animals. 
Table 3 Gross abnormalities observed during necropsy or during sample preparation

\begin{tabular}{|c|c|c|c|c|c|c|c|}
\hline Diet & $\begin{array}{l}\text { Intestinal } \\
\text { redness }\end{array}$ & $\begin{array}{l}\text { Spleen } \\
\text { pigmentation }\end{array}$ & $\begin{array}{l}\text { Spleen - white } \\
\text { nodules }\end{array}$ & $\begin{array}{l}\text { Joint/bone } \\
\text { deformities }\end{array}$ & $\begin{array}{l}\text { Small left } \\
\text { ventricle }\end{array}$ & $\begin{array}{l}\text { Lung discoloration - } \\
\text { gray }\end{array}$ & $\begin{array}{l}\text { Lung discoloration - } \\
\text { red }\end{array}$ \\
\hline KO & 3 & 1 & & & 1 & 2 & \\
\hline K8 & 1 & & & & 3 & I & \\
\hline $\mathrm{K} 17$ & I & & 4 & & 2 & & \\
\hline \multirow[t]{2}{*}{ K33 } & 1 & & 2 & 8 & 1 & & 2 \\
\hline & $\begin{array}{l}\text { Kidney } \\
\text { fibrosis }\end{array}$ & $\begin{array}{l}\text { Kidney/bladder } \\
\text { stones }\end{array}$ & $\begin{array}{l}\text { Unilateral } \\
\text { renal atrophy }\end{array}$ & Pale kidney & $\begin{array}{l}\text { Red renal } \\
\text { pelvis }\end{array}$ & $\begin{array}{l}\text { Kidney - mottled } \\
\text { appearance }\end{array}$ & Kidney cyst \\
\hline K0 & 1 & & & 1 & & & \\
\hline K8 & I & 1 & & & 1 & & \\
\hline $\mathrm{K} 17$ & & & & & & I & \\
\hline K33 & & & I & & & & I \\
\hline
\end{tabular}

Note: The numbers represent the number of animals with the finding.

was significantly different from control only for K33 females. There was no effect of administration of krill meal at the $8 \%$ or $17 \%$ level on liver concentrations of copper, cadmium, or arsenic. While there was a significant increase in zinc content of the liver of $\mathrm{K} 8$ males $(P<0.05)$, the increase was slight. There was no such increase in males in the K17 group. Kidney tissue concentrations of copper, cadmium, arsenic, and zinc are shown in Table 8. Copper concentrations were lower in the kidney compared to liver concentrations (as expected) and were not affected by ingestion of krill meal. Although zinc levels tended to increase in kidneys of K33 females, the effect was not statistically significant. Kidney cadmium levels increased with increasing dietary krill meal inclusion, and were significantly higher in K33 females than K8 females. Arsenic decreased linearly with increasing krill inclusion and was significantly lower in K33 males and females than their respective controls. There was no effect of administration of krill meal at the $8 \%$ or $17 \%$ level on kidney concentrations of copper, cadmium, arsenic, or zinc.

Table 4 Glycogen content of liver sections as determined using PAS staining

\begin{tabular}{llllll}
\hline & $\mathbf{n}$ & Absent & Low & Moderate & High \\
\hline Males & & & & & \\
K0 & 7 & 0 & 0 & I & 6 \\
K8 & 8 & 0 & 0 & 3 & 5 \\
KI7 & 8 & 1 & 1 & 3 & 4 \\
K33 & 8 & I & 3 & 2 & 2 \\
Females & & & & & \\
K0 & 8 & 0 & 0 & 1 & 7 \\
K8 & 8 & 0 & 1 & 1 & 6 \\
KI7 & 8 & 0 & 1 & 3 & 4 \\
K33 & 8 & 2 & 1 & 2 & 3 \\
\hline
\end{tabular}

Note: The numbers represent the number of animals with the finding.

Abbreviations: PAS, periodic acid-Schiff; $n$, number of animals.

\section{Blood characteristics}

There was no effect of Antarctic krill on RBC, HGB, HCT, $\mathrm{MCV}$, or platelet count (Table 9). MCHC decreased and RDW increased in group K33 animals; however, only the MCHC of K33 females and the RDW of K33 males were significantly different from controls $(P<0.05)$. There were no significant differences in the total or differential WBC between treated animals and controls (Table 10). The blood biochemistry profiles yielded similar results in males and females. There was no effect of Antarctic krill on plasma electrolytes (inorganic P, $\mathrm{Ca}, \mathrm{Na}, \mathrm{K}$, or $\mathrm{Cl}$ ) (Table 11). Notable clinical chemistry findings included higher alkaline phosphatase (AP) and amylase in K33 males, decreased urea and creatinine in K33 males and females, and decreased bile acids in K33 females $(P<0.05)$ (Table 12). There was no significant effect of Antarctic krill on cholesterol, triglycerides, or glucose in males or females (Table 13). Free fatty acids increased in K17 and K33 males, but not in any female groups.

\section{Discussion Growth}

In the current study, the safety of Antarctic krill meal in feeds for juvenile mink at various inclusion levels was investigated. The animals grew well during the experimental period and the BWs at the end of the trial were similar to those reported for black mink of similar age ${ }^{29}$ indicating favorable environmental conditions. There are only a few published studies on Atlantic krill as feed for animals and none with mink, dogs, or cats. Results of a study conducted with Atlantic salmon are consistent with the present study showing that, regarding the production indicators such as growth and feed utilization, Antarctic krill can replace good fishmeal at high proportions. $^{30}$ 

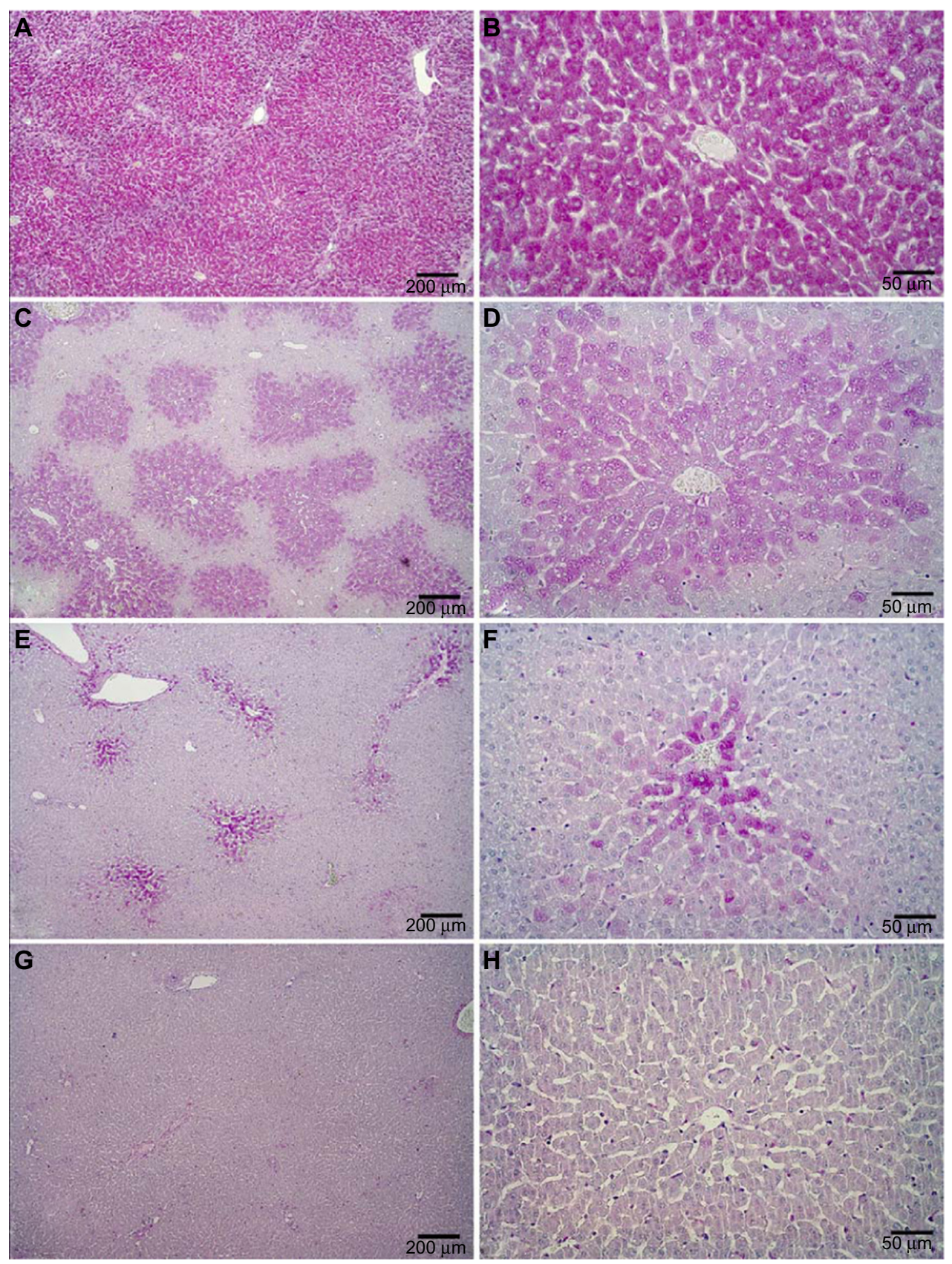

Figure 2 Illustration of the evaluation criteria used for semiquantification of periodic acid-Schiff staining indicating glycogen accumulation in the liver. Notes: (A and $\mathbf{B})$ High; ( $\mathbf{C}$ and $\mathbf{D})$ moderate; (E and $\mathbf{F})$ low; and $(\mathbf{G}$ and $\mathbf{H})$ absent.

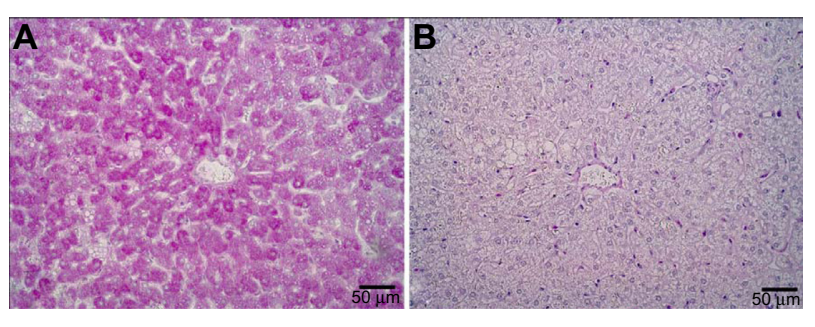

Figure 3 Periodic acid-Schiff staining of diastase pretreated sections confirming that the periodic acid-Schiff staining in the liver was due to glycogen.

Notes: (A) From a female fed the K0 diet; (B) from a female fed the KI7 diet.

\section{Organ weights}

Relative weights of the stomach of males and females and rectum of females were significantly higher in the K33 group than in controls. It is possible that increased gastrointestinal organ weights are related to the presence of chitin, an indigestible polyglucosamine that exhibits properties similar to those of dietary fiber. Fiber has been shown to increase gastrointestinal tract relative weights in a variety of animals, including rats and swine. ${ }^{31-33}$ Fiber may stimulate gut growth 
Table 5 Frequency of focal inflammatory lesions in the liver

\begin{tabular}{llllll}
\hline & $\mathbf{n}$ & None & $\begin{array}{l}\text { Focal } \\
(\mathbf{I})\end{array}$ & $\begin{array}{l}\text { Multifocal } \\
(\mathbf{2}-\mathbf{3})\end{array}$ & $\begin{array}{l}\text { Multifocal } \\
(\geq \mathbf{4})\end{array}$ \\
\hline Males & & & & & \\
K0 & 7 & 5 & $\mathrm{I}$ & $\mathrm{I}$ & 0 \\
K8 & 8 & 4 & 3 & $\mathrm{I}$ & 0 \\
KI7 & 8 & 2 & $\mathrm{I}$ & 2 & 3 \\
K33 & 8 & 2 & $\mathrm{I}$ & $\mathrm{I}$ & 4 \\
Females & & & & & \\
K0 & 8 & 8 & 0 & 0 & 0 \\
K8 & 8 & 6 & $\mathrm{I}$ & $\mathrm{I}$ & 0 \\
KI7 & 8 & 3 & 2 & 3 & 0 \\
K33 & 8 & 4 & $\mathrm{I}$ & 0 & 3 \\
\hline
\end{tabular}

Note: The numbers represent the number of animals with the finding. Abbreviation: $n$, number of animals.
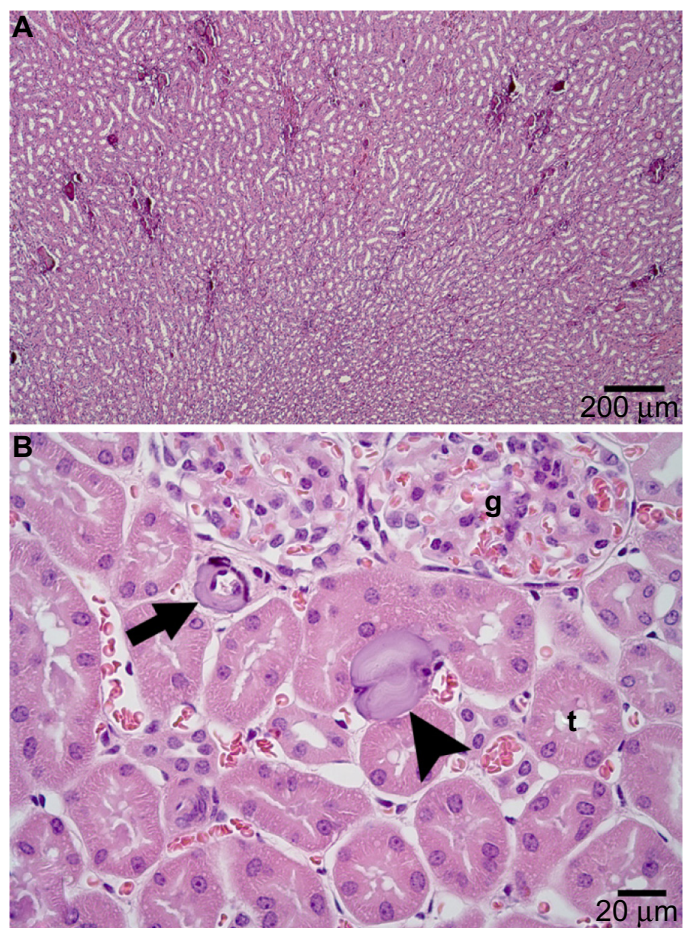

Figure 4 Crystalline material observed within the kidney of a male fed the KI7 diet. Notes: (A) Crystalline material was most often located in the $t$ near the corticomedullary junction. (B) Crystalline material was occasionally observed outside of the $t$ (arrowhead) or the surrounding blood vessels (arrow).

Abbreviations: g, glomerulus; $t$, tubule.

Table 6 Frequency of crystalline material within kidney tissue

\begin{tabular}{llllll}
\hline & $\mathbf{n}$ & None & Rare & Occasional & Numerous \\
\hline Males & & & & & \\
K0 & 7 & 1 & 3 & 3 & 0 \\
K8 & 8 & 1 & $\mathrm{I}$ & $\mathrm{I}$ & 5 \\
KI7 & 8 & 0 & 0 & 0 & 8 \\
K33 & 8 & 0 & 0 & 3 & 5 \\
Females & & & & & \\
K0 & 8 & 1 & 5 & 2 & 0 \\
K8 & 8 & 0 & 6 & 0 & 2 \\
KI7 & 8 & 0 & 0 & 2 & 6 \\
K33 & 8 & 0 & 1 & 1 & 6 \\
\hline
\end{tabular}

Note: The numbers represent the number of animals with the finding. Abbreviation: $n$, number of animals.

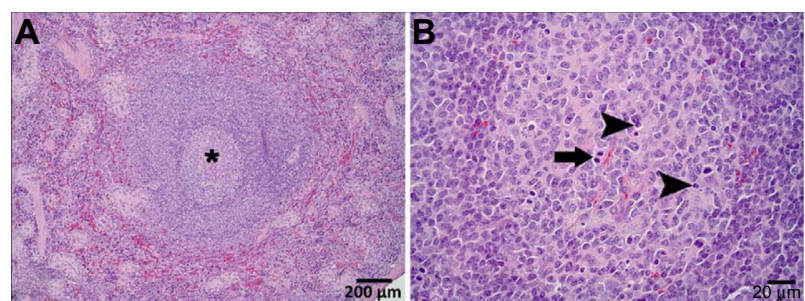

Figure $5 \mathrm{~A}$ reactive lymphoid follicle in the spleen of a male fed the $\mathrm{K} 33$ diet. Notes: (A) The germinal center (asterisk) is apparent. (B) Mitotic figures (arrow) and apoptotic bodies (arrowheads) within the germinal center.

by supplying substrate to microbiota for the production of short chain fatty acids. ${ }^{34}$ The reason for the slight, but statistically significant, increase in the relative heart weight of females in the K33 group is unknown, but that result was not considered toxicologically relevant because of lack of other findings in heart.

The amount of glycogen in the liver decreased in K17 and $\mathrm{K} 33$ animals, as indicated by the histological examination. The relevance of decreased liver glycogen is unclear. Plasma glucose concentrations in all groups were normal, indicating that low liver glycogen did not significantly affect the ability to maintain blood glucose levels. The findings were similar to those of the previous study in adult female mink provided $35 \%$ krill meal in the diet during pregnancy and lactation. ${ }^{27}$ Although liver weights tended to decrease (particularly in the K33 group), there were no significant differences between liver weights of any groups of animals provided Antarctic krill compared to controls. The mechanism for the effect of high dosages of Antarctic krill on liver glycogen in mink is unknown, but it may be due to lower energy assimilation, increased glycogenolysis, or some combination thereof. The fact that serum amylase was increased in the K33 group suggests that glycogenolysis was stimulated by inclusion of krill meal at the $33 \%$ level. Fluorine can affect various enzyme systems, ${ }^{35}$ including those involved in glucose

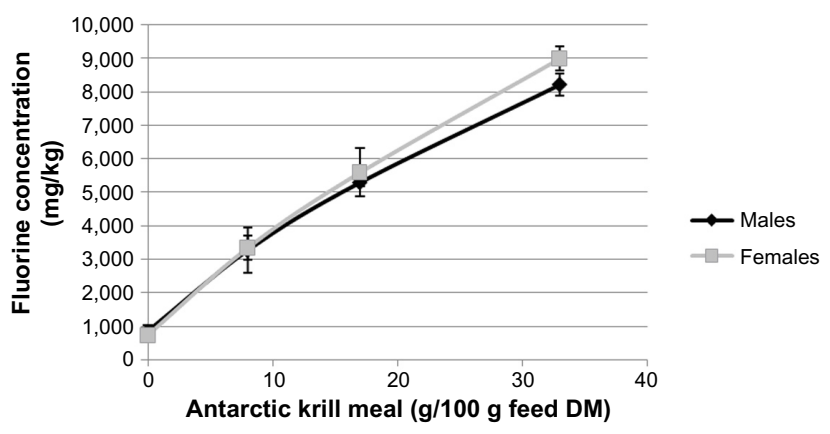

Figure 6 Bone (left femur) fluoride concentration showing a clear increase with increasing dietary fluorine concentration.

Note: Data are presented as the mean \pm standard deviation. Abbreviation: DM, dry matter. 


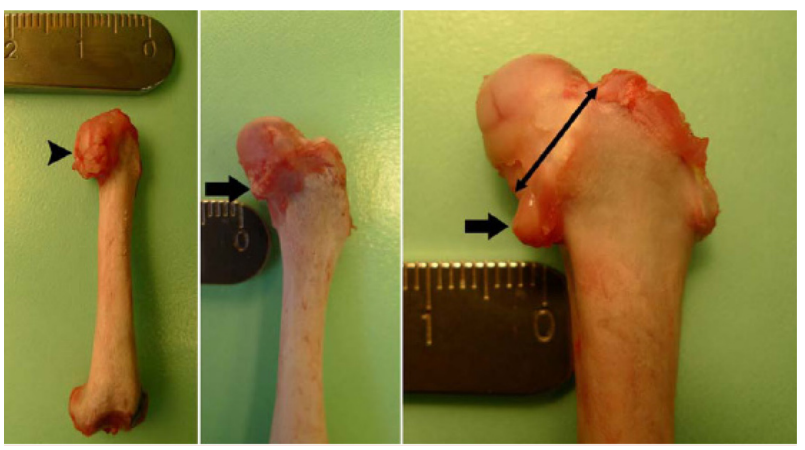

Figure 7 Bone deformities of the left femur.

Notes: Femoral head malformation (arrowhead), calcification of the joint capsule (arrows), or thickening of the femoral neck (double-ended arrow) were found in most males and one female in the $\mathrm{K} 33$ group.

phosphorylation ${ }^{36}$ and glucose tolerance. ${ }^{37}$ Fluorine may also interfere with glycogen deposition by impeding glucose entry into cells. ${ }^{36}$

\section{Organ metals}

The dietary copper level for the $\mathrm{K} 33$ diet $(31.1 \mathrm{mg} / \mathrm{kg})$ exceeded the EU limit of $25 \mathrm{mg}$ copper $/ \mathrm{kg}$ in complete feedstuffs for animals. The level of copper would have been above this limit even if the mineral mix had been free of copper because it would have only reduced the dietary copper level by $1.8 \mathrm{mg} / \mathrm{kg}$. Males ingesting the K33 diet had significantly higher amounts of copper in liver than study controls and healthy ranch mink of similar age fed on a diet containing approximately $20 \mathrm{mg}$ copper $/ \mathrm{kg}$ diet on a dry weight basis $(14.2 \pm 8.48 \mathrm{ppm}) .^{38}$ The level of zinc in the liver of K33 males

Table $7 \mathrm{Cu}, \mathrm{Cd}$, As, and $\mathrm{Zn}$ concentrations in liver tissue

\begin{tabular}{llllll}
\hline & $\mathbf{n}^{*}$ & $\begin{array}{l}\mathrm{Cu} \\
(\mathbf{m g} / \mathbf{k g})\end{array}$ & $\begin{array}{l}\mathbf{C d} \\
(\mathbf{m g} / \mathbf{k g})\end{array}$ & $\begin{array}{l}\text { As } \\
(\mathbf{m g} / \mathbf{k g})\end{array}$ & $\begin{array}{l}\mathbf{Z n} \\
(\mathbf{m g} / \mathbf{k g})\end{array}$ \\
\hline Males & & & & & \\
K0 & 4 & $7.2 \pm 1.6^{\mathrm{a}}$ & $0.029 \pm 0.005^{\mathrm{a}}$ & $0.79 \pm 0.18$ & $31.2 \pm 3.4^{\mathrm{a}}$ \\
K8 & 4 & $15.0 \pm 4.2^{\mathrm{a}}$ & $0.030 \pm 0.003^{\mathrm{a}}$ & $0.66 \pm 0.17$ & $37.5 \pm 3.1^{\mathrm{b}, \mathrm{c}}$ \\
KI7 & 4 & $14.5 \pm 2.6^{\mathrm{a}, \mathrm{b}}$ & $0.035 \pm 0.004^{\mathrm{a}}$ & $0.61 \pm 0.15$ & $34.2 \pm 2.1^{\mathrm{a}-\mathrm{c}}$ \\
K33 & 4 & $37.0 \pm 11.6^{\mathrm{b}}$ & $0.051 \pm 0.002^{\mathrm{b}}$ & $0.46 \pm 0.22$ & $46.2 \pm 1.9^{\mathrm{b}}$ \\
P-value & & 0.0002 & $<0.0001$ & 0.135 & $<0.000 \mathrm{I}$ \\
Females & & & & & \\
K0 & 4 & $15.8 \pm 5.0$ & $0.033 \pm 0.003^{\mathrm{a}}$ & $0.69 \pm 0.11^{\mathrm{a}}$ & $32.0 \pm 2.9$ \\
K8 & 4 & $28.8 \pm I 1.5$ & $0.034 \pm 0.005^{\mathrm{a}, \mathrm{b}}$ & $0.64 \pm 0.21^{\mathrm{a}}$ & $37.0 \pm 2.2$ \\
KI7 & 4 & $22.5 \pm 5.7$ & $0.040 \pm 0.004^{\mathrm{a}, \mathrm{b}}$ & $0.42 \pm 0.02^{\mathrm{a}, \mathrm{b}}$ & $35.8 \pm 3.5$ \\
K33 & 4 & $20.8 \pm 5.1$ & $0.052 \pm 0.015^{\mathrm{b}}$ & $0.28 \pm 0.12^{\mathrm{b}}$ & $37.0 \pm 2.2$ \\
P-value & & 0.150 & 0.008 & 0.0001 & 0.075
\end{tabular}

Notes: Values are presented as the mean \pm standard deviation; $\mathrm{Cu}$ data for males and $\mathrm{Cd}$ and As data for females were analyzed using a Kruskal-Wallis test. All other data were analyzed by ANOVA; values with different superscripts are significantly different from each other $(P<0.05)$; *samples were pooled (two individuals per sample) prior to analysis, with the exception of one of the samples from $\mathrm{KO}$ males due to $n=7$ in this group.

Abbreviations: $n$, number of samples; ANOVA, analysis of variance; $\mathrm{Cu}$, copper; Cd, cadmium; As, arsenic; Zn, zinc.
Table $8 \mathrm{Cu}, \mathrm{Cd}, \mathrm{As}$, and $\mathrm{Zn}$ concentrations in kidney tissue

\begin{tabular}{llllll}
\hline & $\mathbf{n}^{*}$ & $\begin{array}{l}\mathrm{Cu} \\
(\mathbf{m g} / \mathbf{k g})\end{array}$ & $\begin{array}{l}\mathbf{C d} \\
(\mathbf{m g} / \mathbf{k g})\end{array}$ & $\begin{array}{l}\text { As } \\
(\mathbf{m g} / \mathbf{k g})\end{array}$ & $\begin{array}{l}\mathbf{Z n} \\
(\mathbf{m g} / \mathbf{k g})\end{array}$ \\
\hline Males & & & & & \\
K0 & 4 & $3.48 \pm 0.30$ & $0.044 \pm 0.005$ & $0.78 \pm 0.09^{\mathrm{a}}$ & $19.2 \pm 0.9$ \\
K8 & 4 & $3.50 \pm 0.18$ & $0.042 \pm 0.007$ & $0.67 \pm 0.15^{\mathrm{a}, \mathrm{b}}$ & $20.2 \pm 0.5$ \\
$\mathrm{KI7}$ & 4 & $3.28 \pm 0.17$ & $0.053 \pm 0.006$ & $0.58 \pm 0.13^{\mathrm{a}, \mathrm{b}}$ & $19.8 \pm 2.2$ \\
K33 & 4 & $3.90 \pm 1.40$ & $0.059 \pm 0.014$ & $0.40 \pm 0.16^{\mathrm{b}}$ & $20.5 \pm 1.7$ \\
P-value & & 0.680 & 0.066 & 0.012 & 0.663 \\
Females & & & & & \\
K0 & 4 & $3.78 \pm 0.22$ & $0.050 \pm 0.006^{\mathrm{a}, \mathrm{b}}$ & $0.81 \pm 0.08^{\mathrm{a}}$ & $20.2 \pm 1.5$ \\
K8 & 4 & $3.80 \pm 0.18$ & $0.049 \pm 0.003^{\mathrm{a}}$ & $0.78 \pm 0.22^{\mathrm{a}}$ & $21.2 \pm 2.6$ \\
KI7 & 4 & $3.78 \pm 0.05$ & $0.062 \pm 0.007^{\mathrm{a}, \mathrm{b}}$ & $0.55 \pm 0.11^{\mathrm{a}, \mathrm{b}}$ & $22.0 \pm 1.4$ \\
K33 & 4 & $3.88 \pm 0.33$ & $0.070 \pm 0.017^{\mathrm{b}}$ & $0.33 \pm 0.10^{\mathrm{b}}$ & $23.8 \pm 3.1$ \\
$P$-value & & 0.973 & 0.030 & 0.001 & 0.223 \\
\hline
\end{tabular}

Notes: Values are presented as the mean \pm standard deviation; $\mathrm{Cu}$ and $\mathrm{As}$ data for females were analyzed using a nonparametric Kruskal-Wallis test due to significantly different standard deviations; all other data were analyzed by ANOVA; values with different superscripts are significantly different from each other $(P<0.05)$; * samples were pooled (two individuals per sample) prior to analysis, with the exception of one of the samples from $\mathrm{KO}$ male due to $\mathrm{n}=7$ in this group.

Abbreviation: $\mathrm{n}$, number of samples; ANOVA, analysis of variance; $\mathrm{Cu}$, copper; $\mathrm{Cd}$, cadmium; As, arsenic; Zn, zinc.

also was higher than that of control males. The reason for this is unclear because the zinc content of Antarctic krill ${ }^{17}$ is typically lower than that of fishmeal $(90 \mathrm{ppm}) .{ }^{39}$ The slight increase in zinc content of the liver was not considered to be toxicologically relevant. Animals in the K33 group also exhibited slight, but statistically significant, increases in kidney and liver cadmium compared to control. The reason for this increase is unclear, because the cadmium content of Antarctic krill is typically $<1 \mathrm{ppm} .{ }^{17}$ Animals receiving Antarctic krill meal showed dose-dependent decreases in liver and kidney arsenic (a beneficial effect), suggesting that the arsenic content of the krill meal was lower than that of the fishmeal used in the control diet.

\section{Bone structure and fluoride concentration}

Fluorine levels in all diets with krill exceeded the current EU limit for fluorine in animal feeds. The effects of dietary fluorine (as sodium fluoride $[\mathrm{NaF}]$ ) on mink have been previously investigated to a limited extent. ${ }^{40,41} \mathrm{NaF}$ is rapidly absorbed in the acidic environment of the stomach as hydrogen fluoride, with absorption reported as high as $99 \%$ in the fasted state. ${ }^{42}$ The bioavailability of fluorine in krill, although lower than $\mathrm{NaF}$, remains high, although reports vary. In rats, the absorption of fluorine from krill can reach $80 \%{ }^{43}$ However, substances in feeds can affect fluorine absorption. The presence of food reduces the efficiency of fluorine absorption to $50 \%-80 \% .{ }^{42}$ Calcium can bind fluorine, a well-known phenomenon in caries prevention, ${ }^{44}$ forming an 
Table 9 Red blood cell indices of mink fed the experimental diets

\begin{tabular}{|c|c|c|c|c|c|c|c|c|}
\hline & $\mathbf{n}$ & RBC $\left(\times 10^{12} / L\right)$ & HGB (g/L) & HCT (L/L) & $\operatorname{MCV}(\mathrm{fL})$ & MCHC (g/L) & RDW (\%) & PLT $\left(\times 10^{9} / L\right)$ \\
\hline \multicolumn{9}{|l|}{ Males } \\
\hline Ko & 7 & $9.88 \pm 0.69$ & $183 \pm 14$ & $0.60 \pm 0.04$ & $60.1 \pm 3.7$ & $308 \pm 12$ & $13.6 \pm 0.8^{a}$ & $686 \pm 178$ \\
\hline K8 & 8 & $9.48 \pm 0.31$ & $178 \pm 9$ & $0.58 \pm 0.03$ & $61.2 \pm 2.4$ & $306 \pm 8$ & $13.4 \pm 0.7^{\mathrm{a}}$ & $624 \pm 112$ \\
\hline $\mathrm{K} 17$ & 8 & $10.04 \pm 0.47$ & $184 \pm 5$ & $0.60 \pm 0.03$ & $60.2 \pm 3.1$ & $304 \pm 11$ & $13.3 \pm 0.6^{\mathrm{a}}$ & $607 \pm 118$ \\
\hline K33 & 8 & $9.68 \pm 1.08$ & $169 \pm 20$ & $0.57 \pm 0.07$ & $58.7 \pm 2.2$ & $298 \pm 8$ & $14.9 \pm 0.8^{b}$ & $769 \pm 204$ \\
\hline$P$-value & & 0.421 & 0.317 & 0.434 & 0.412 & 0.166 & 0.0004 & 0.181 \\
\hline \multicolumn{9}{|c|}{ Females } \\
\hline KO & 6 & $9.68 \pm 0.61$ & $187 \pm 8$ & $0.59 \pm 0.03$ & $61.0 \pm 2.3$ & $318 \pm 16^{a}$ & $13.3 \pm 0.4$ & $533 \pm 153$ \\
\hline K8 & 7 & $10.18 \pm 0.75$ & $186 \pm 9$ & $0.60 \pm 0.04$ & $59.4 \pm 1.7$ & $308 \pm 14^{\mathrm{a}, \mathrm{b}}$ & $13.4 \pm 0.6$ & $659 \pm 175$ \\
\hline $\mathrm{K} 17$ & 7 & $9.62 \pm 0.79$ & $180 \pm 9$ & $0.59 \pm 0.03$ & $61.3 \pm 2.4$ & $306 \pm 10^{a, b}$ & $13.4 \pm 0.2$ & $653 \pm 97$ \\
\hline K33 & 8 & $9.54 \pm 0.53$ & $164 \pm 24$ & $0.56 \pm 0.06$ & $58.6 \pm 4.6$ & $292 \pm 14^{b}$ & $15.5 \pm 2.1$ & $765 \pm 314$ \\
\hline$P$-value & & 0.298 & 0.044 & 0.300 & 0.295 & 0.011 & 0.037 & 0.440 \\
\hline
\end{tabular}

Notes: Values are presented as the mean \pm standard deviation. Values for some female animals (two K0, one K8, and one K 7 ) were not obtained because the blood sample was not taken or was not sufficient for the analysis. RBC and HGB data for males and HGB, RDW, and platelet data for females were analyzed using a Kruskal-Wallis test; all other data were analyzed by ANOVA; values with different superscripts are significantly different from each other $(P<0.05)$.

Abbreviations: $n$, number of animals; RBC, red blood cell count; $\mathrm{HGB}$, hemoglobin concentration; $\mathrm{HCT}$, hematocrit; $\mathrm{MCV}$, mean cell volume; HCHC, mean cell hemoglobin concentration; RDW, red blood cell distribution width; PLT, platelet count; ANOVA, analysis of variance.

Table IO WBC of mink fed the experimental diets

\begin{tabular}{|c|c|c|c|c|c|c|c|}
\hline & n & $\begin{array}{l}\text { WBC } \\
\left(\times 10^{9} / L\right)\end{array}$ & $\begin{array}{l}\text { Neutrophils } \\
\left(\times 10^{9} / L\right)\end{array}$ & $\begin{array}{l}\text { Lymphocytes } \\
\left(\times 10^{\circ} / L\right)\end{array}$ & $\begin{array}{l}\text { Monocytes } \\
\left(\times 10^{9} / L\right)\end{array}$ & $\begin{array}{l}\text { Eosinophils } \\
\left(\times 10^{9} / L\right)\end{array}$ & $\begin{array}{l}\text { Basophils } \\
\left(\times 10^{9} / \mathrm{L}\right)\end{array}$ \\
\hline \multicolumn{8}{|l|}{ Males } \\
\hline $\mathrm{KO}$ & 7 & $9.20 \pm 5.07$ & $4.06 \pm 2.75^{\mathrm{a}, \mathrm{b}}$ & $4.23 \pm 2.04$ & $0.54 \pm 0.34$ & $0.3 I \pm 0.07$ & $0.03 \pm 0.05$ \\
\hline K8 & 8 & $6.88 \pm 2.03$ & $2.89 \pm 0.9 \mathrm{I}^{\mathrm{a}}$ & $3.40 \pm 1.37$ & $0.26 \pm 0.11$ & $0.26 \pm 0.13$ & $0.06 \pm 0.07$ \\
\hline $\mathrm{K} 17$ & 8 & $9.58 \pm 6.30$ & $4.26 \pm 3.48^{\mathrm{a}, \mathrm{b}}$ & $4.19 \pm 2.26$ & $0.52 \pm 0.29$ & $0.49 \pm 0.58$ & $0.25 \pm 0.55$ \\
\hline K33 & 8 & $11.95 \pm 5.58$ & $5.12 \pm 1.37^{b}$ & $5.52 \pm 3.58$ & $0.58 \pm 0.29$ & $0.6 I \pm 0.57$ & $0.60 \pm 0.67$ \\
\hline$P$-value & & 0.272 & 0.026 & 0.398 & 0.102 & 0.820 & 0.139 \\
\hline \multicolumn{8}{|c|}{ Females } \\
\hline KO & 6 & $5.87 \pm 2.16$ & $1.98 \pm 0.58$ & $3.32 \pm 1.63$ & $0.25 \pm 0.16$ & $0.28 \pm 0.15$ & $0.02 \pm 0.04$ \\
\hline K8 & 7 & $6.54 \pm 3.05$ & $3.03 \pm 2.18$ & $2.84 \pm 1.05$ & $0.30 \pm 0.21$ & $0.30 \pm 0.21$ & $0.03 \pm 0.05$ \\
\hline KI7 & 7 & $5.79 \pm 3.56$ & $2.26 \pm 1.09$ & $3.01 \pm 2.43$ & $0.33 \pm 0.20$ & $0.19 \pm 0.13$ & $0.01 \pm 0.04$ \\
\hline K33 & 8 & $4.14 \pm 2.22$ & $2.01 \pm 1.05$ & $1.68 \pm 0.97$ & $0.26 \pm 0.15$ & $0.10 \pm 0.08$ & $0.06 \pm 0.11$ \\
\hline$P$-value & & 0.408 & 0.730 & 0.245 & 0.849 & 0.054 & 0.672 \\
\hline
\end{tabular}

Table I I Plasma electrolytes of mink fed the experimental diets

\begin{tabular}{lllllll}
\hline & $\mathbf{n}$ & \multicolumn{1}{l}{ Inorganic $\mathbf{P}(\mathbf{m m o l} / \mathbf{L})$} & $\mathbf{C a}(\mathbf{m m o l} / \mathbf{L})$ & $\mathbf{N a}(\mathbf{m m o l} / \mathbf{L})$ & $\mathbf{K}(\mathbf{m m o l} / \mathbf{L})$ & $\mathbf{C l}(\mathbf{m m o l} / \mathbf{L})$ \\
\hline Males & & & & & & \\
K0 & 7 & $2.29 \pm 0.52$ & $2.87 \pm 0.10$ & $160.1 \pm 4.2$ & $7.24 \pm 0.88$ & $116.6 \pm 2.8$ \\
K8 & 8 & $2.06 \pm 0.47$ & $2.84 \pm 0.21$ & $159.5 \pm 3.6$ & $7.24 \pm 1.32$ & $116.1 \pm 3.9$ \\
KI7 & 8 & $2.02 \pm 0.35$ & $2.89 \pm 0.11$ & $159.0 \pm 3.3$ & $6.94 \pm 0.82$ & $117.1 \pm 1.9$ \\
K33 & 8 & $2.41 \pm 0.34$ & $2.92 \pm 0.10$ & $160.3 \pm 4.0$ & $7.36 \pm 0.86$ & $117.5 \pm 1.6$ \\
$P$-value & & 0.236 & 0.652 & 0.903 & 0.850 & 0.756 \\
Females & & & & & & \\
K0 & 7 & $1.89 \pm 0.45$ & $2.74 \pm 0.11$ & $158.9 \pm 3.7$ & $1.56 \pm 1.44$ & $117.0 \pm 3.0$ \\
K8 & 7 & $1.48 \pm 0.54$ & $2.77 \pm 0.10$ & $158.4 \pm 3.1$ & $6.73 \pm I .16$ & $116.6 \pm 2.2$ \\
KI7 & 8 & $2.20 \pm 0.58$ & $2.78 \pm 0.07$ & $158.8 \pm 3.2$ & $7.55 \pm 1.54$ & $116.4 \pm 2.5$ \\
K33 & 8 & $2.31 \pm 0.40$ & $2.76 \pm 0.05$ & $158.6 \pm 2.6$ & $7.49 \pm 1.52$ & $117.5 \pm 2.3$ \\
$P$-value & & 0.206 & 0.888 & 0.995 & 0.643 & 0.820 \\
\hline
\end{tabular}

Notes: Values are presented as the mean \pm standard deviation; values for some female animals (one K0 and one K8) were not obtained because the blood sample was not taken or was not sufficient for the analysis; all data were analyzed by analysis of variance; no values were significantly different from each other $(P<0.05)$.

Abbreviations: $\mathrm{n}$, number of animals; $\mathrm{P}$, phosphorus; $\mathrm{Ca}$, calcium; $\mathrm{Na}$, Sodium; $\mathrm{P}$, potassium; $\mathrm{Cl}$, chloride. 
Table I 2 Blood biochemistry profile of mink fed the experimental diets

\begin{tabular}{|c|c|c|c|c|c|}
\hline & \multicolumn{4}{|l|}{ Diet } & \multirow[t]{2}{*}{$P$-value } \\
\hline & KO & $\mathbf{K 8}$ & $K 17$ & K33 & \\
\hline Males (n) & 7 & 8 & 8 & 8 & \\
\hline AST (U/L) & $166 \pm 115$ & $176 \pm 126$ & $110 \pm 46$ & $110 \pm 65$ & 0.286 \\
\hline ALT (U/L) & $249 \pm 229$ & $26 I \pm 210$ & $100 \pm 30$ & $112 \pm 73$ & 0.092 \\
\hline $\mathrm{AP}(\mathrm{U} / \mathrm{L})$ & $107 \pm 15^{a}$ & $126 \pm 49^{a, b}$ & $146 \pm 52^{\mathrm{a}, \mathrm{b}}$ & $234 \pm 99^{b}$ & 0.013 \\
\hline CK (U/L) & $64 I \pm 460$ & $882 \pm 617$ & $1,067 \pm 809$ & $1,242 \pm 1,624$ & 0.597 \\
\hline Amylase (U/L) & $84 \pm 18^{a}$ & $89 \pm 15^{a, b}$ & $95 \pm 14^{a, b}$ & $109 \pm 13^{b}$ & 0.016 \\
\hline Lipase (U/L) & $25 \pm 3$ & $24 \pm 2$ & $28 \pm 8$ & $27 \pm 3$ & 0.211 \\
\hline Total protein $(\mathrm{g} / \mathrm{L})$ & $67.9 \pm 3.4$ & $66.5 \pm 2.8$ & $66.6 \pm 3.6$ & $67.6 \pm 2.5$ & $0.77 I$ \\
\hline Albumin $(\mathrm{g} / \mathrm{L})$ & $39.9 \pm 4.6$ & $40.5 \pm 2.4$ & $40.4 \pm 2.4$ & $38.4 \pm 2.2$ & $0.48 I$ \\
\hline Globulin (g/L) & $28.0 \pm 1.9$ & $26.0 \pm 2.4$ & $26.2 \pm 2.8$ & $29.2 \pm 2.8$ & 0.052 \\
\hline Urea (mmol/L) & $10.6 \pm 1.9^{\mathrm{a}}$ & $8.8 \pm 3.2^{\mathrm{a}, \mathrm{b}}$ & $8.1 \pm 2.5^{\mathrm{a}, \mathrm{b}}$ & $6.2 \pm 1.1^{b}$ & 0.010 \\
\hline Creatinine $(\mu \mathrm{mol} / \mathrm{L})$ & $112 \pm 17^{a}$ & $102 \pm 34^{\mathrm{a}, \mathrm{b}}$ & $78 \pm 20^{\mathrm{a}, \mathrm{b}}$ & $68 \pm 9^{b}$ & 0.006 \\
\hline Bile acids $(\mu \mathrm{mol} / \mathrm{L})$ & $9.4 \pm 4.6$ & $5.5 \pm 4.3$ & $5.0 \pm 3.6$ & $4.2 \pm 3.4$ & 0.082 \\
\hline Total bilirubin $(\mu \mathrm{mol} / \mathrm{L})$ & $0.6 \pm 0.5$ & $0.8 \pm 0.5$ & $0.5 \pm 0.5$ & $0.4 \pm 0.5$ & 0.534 \\
\hline Females (n) & 7 & 7 & 8 & 8 & \\
\hline AST (U/L) & $156 \pm 132$ & $209 \pm 291$ & $333 \pm 328$ & $212 \pm 216$ & 0.585 \\
\hline ALT (U/L) & $153 \pm 139$ & $203 \pm 197$ & $428 \pm 506$ & $236 \pm 244$ & 0.605 \\
\hline $\mathrm{AP}(\mathrm{U} / \mathrm{L})$ & $105 \pm 7$ & $93 \pm 30$ & $118 \pm 20$ & $139 \pm 43$ & 0.034 \\
\hline CK (U/L) & $1,620 \pm 2,493$ & $I, 00 I \pm I, 42 \mid$ & $857 \pm 717$ & $1,436 \pm 1,101$ & 0.491 \\
\hline Amylase (U/L) & $82 \pm 7$ & $87 \pm 14$ & $87 \pm 16$ & $102 \pm 20$ & 0.090 \\
\hline Lipase (U/L) & $31 \pm 3$ & $30 \pm 6$ & $30 \pm 2$ & $3 I \pm 4$ & 0.991 \\
\hline Total protein $(\mathrm{g} / \mathrm{L})$ & $63.9 \pm 3.3$ & $67.1 \pm 1.7$ & $65.4 \pm 2.1$ & $63.9 \pm 2.5$ & 0.056 \\
\hline Albumin $(g / L)$ & $4 I .0 \pm 1.3$ & $40.1 \pm 5.4$ & $40.6 \pm 1.4$ & $38.6 \pm 2.9$ & 0.090 \\
\hline Globulin (g/L) & $22.9 \pm 2.4$ & $27.0 \pm 6.3$ & $24.8 \pm 1.8$ & $25.2 \pm 3.3$ & 0.096 \\
\hline Urea (mmol/L) & $10.0 \pm 1.7^{\mathrm{a}}$ & $9.4 \pm 2.1^{\mathrm{a}, \mathrm{b}}$ & $7.5 \pm 2 . I^{a, b}$ & $7.2 \pm 1.4^{\mathrm{b}}$ & 0.018 \\
\hline Creatinine $(\mu \mathrm{mol} / \mathrm{L})$ & $93 \pm 19^{a}$ & $90 \pm 14^{\mathrm{a}}$ & $79 \pm 19^{a, b}$ & $63 \pm 12^{b}$ & 0.004 \\
\hline Bile acids $(\mu \mathrm{mol} / \mathrm{L})$ & $11.1 \pm 4.6^{\mathrm{a}}$ & $10.7 \pm 8 .\left.\right|^{a, b}$ & $5.6 \pm 3 . I^{a, b}$ & $4.4 \pm 1.8^{b}$ & 0.032 \\
\hline Total bilirubin $(\mu \mathrm{mol} / \mathrm{L})$ & $0.6 \pm 0.5$ & $0.6 \pm 0.5$ & $0.4 \pm 0.5$ & $0.5 \pm 0.5$ & 0.872 \\
\hline
\end{tabular}

Notes: Values are presented as the mean \pm standard deviation; values for some female animals (one K0 and one K8) were not obtained because the blood sample was not taken or was not sufficient for the analysis; AST, ALT, AP, CK, lipase, and creatinine data for males and ALT, AP, CK, albumin, globulin, and bile acid data for females were analyzed using a Kruskal-Wallis test; all other data were analyzed by analysis of variance; values with different superscripts are significantly different from each other $(P<0.05)$.

Abbreviations: $n$, number of animals; AST, aspartate aminotransferase; ALT, alanine aminotransferase; AP, alkaline phosphatase; CK, creatine kinase.

insoluble complex and reducing fluorine absorption from krill. ${ }^{43}$ Bone fluoride concentrations corresponded well with dietary krill inclusion and fluorine concentrations. At the highest dietary krill level, clear indications of skeletal fluorosis were observed and fluoride levels in dried defatted bone exceeded $8,000 \mathrm{mg} / \mathrm{kg}$ in males and reached 9,000 $\mathrm{mg} / \mathrm{kg}$ in females. Deformations of the femoral head and neck were also observed in $7 / 8$ males and $1 / 8$ females in this group. Even at the lowest dietary krill inclusion level, bone fluoride reached levels of approximately $3,300 \mathrm{mg} / \mathrm{kg}$. Aulerich et $\mathrm{al}^{40}$ reported similar fluoride concentrations in ashed bone of 3-month-old mink fed diets containing between $33 \mathrm{mg} \mathrm{NaF} / \mathrm{kg}$ and $194 \mathrm{mg} \mathrm{NaF} / \mathrm{kg}$ for 382 days. Schupe et $\mathrm{al}^{41}$ reported fluoride concentrations of $5,110 \mathrm{mg} / \mathrm{kg}$ in the dried defatted femurs of mink kits fed a diet containing $111.5 \mathrm{mg}$ fluorine/kg for 7 months, and 4,716 $\mathrm{mg}$ fluoride $/ \mathrm{kg}$ in the femurs of adult males fed a diet containing $287 \mathrm{mg}$ fluorine $/ \mathrm{kg}$ for 8 months. These findings led the authors to recommend maximum fluorine concentrations in diets for mink of $50 \mathrm{mg} / \mathrm{kg}$ for breeding stock and $100 \mathrm{mg} / \mathrm{kg}$ in animals raised for fur. ${ }^{41}$

\section{Blood characteristics}

Values of some blood chemistry variables in K17 and K33 animals were significantly different from control $(P<0.05)$. AP activity in blood plasma was increased in K33 males, which may be related to the high fluorine content of the krill. Serum AP has been reported to be elevated in rats given $50 \mathrm{ppm}$ fluoride in drinking water for 60 days, ${ }^{45}$ and mink fed diets containing 194 ppm supplemental fluorine (from NaF).$^{40}$ Increased AP activity is associated with increased osteoblast activity ${ }^{46}$ and thus may indicate increased bone deposition and/or mineralization. AP is not, however, specific for bone, but it can also indicate 
Table I 3 Plasma cholesterol, triglycerides, free fatty acids, and glucose of mink fed the experimental diets

\begin{tabular}{llllll}
\hline & $\mathbf{n}$ & $\begin{array}{l}\text { Cholesterol } \\
(\mathbf{m m o l} / \mathbf{L})\end{array}$ & $\begin{array}{l}\text { Triglycerides } \\
(\mathbf{m m o l} / \mathbf{L})\end{array}$ & $\begin{array}{l}\text { Free } \\
\text { fatty acids } \\
(\mathbf{m m o l} / \mathbf{L})\end{array}$ & $\begin{array}{l}\text { Glucose } \\
(\mathbf{m m o l} / \mathbf{L})\end{array}$ \\
\hline Males & & & & & \\
K0 & 7 & $6.3 \pm 0.7$ & $1.6 \pm 0.8$ & $0.2 \pm 0.1^{\mathrm{a}}$ & $8.9 \pm 2.1$ \\
K8 & 8 & $6.1 \pm 1.2$ & $1.5 \pm 0.9$ & $0.6 \pm 0.4^{\mathrm{a}, \mathrm{b}}$ & $9.8 \pm 2.9$ \\
KI7 & 8 & $6.5 \pm 1.3$ & $1.4 \pm 0.6$ & $0.6 \pm 0.4^{\mathrm{b}}$ & $8.4 \pm 1.7$ \\
K33 & 8 & $7.4 \pm 1.4$ & $1.2 \pm 0.4$ & $0.8 \pm 0.5^{\mathrm{b}}$ & $7.8 \pm 1.5$ \\
P-value & & 0.198 & 0.715 & 0.004 & 0.329 \\
Females & & & & & \\
K0 & 7 & $6.9 \pm 0.4$ & $1.7 \pm 0.3$ & $0.3 \pm 0.3$ & $8.3 \pm 1.2$ \\
K8 & 7 & $6.9 \pm 0.9$ & $1.6 \pm 0.4$ & $0.6 \pm 0.5$ & $8.9 \pm 2.4$ \\
KI7 & 8 & $7.3 \pm 0.5$ & $1.6 \pm 0.5$ & $0.4 \pm 0.2$ & $9.0 \pm 2.0$ \\
K33 & 8 & $7.0 \pm 0.6$ & $1.4 \pm 0.5$ & $0.6 \pm 0.4$ & $8.5 \pm 1.7$ \\
P-value & & 0.626 & 0.556 & 0.455 & 0.852 \\
\hline
\end{tabular}

Notes: Values are presented as mean \pm standard deviation; values for some female animals (one $\mathrm{K} 0$ and one $\mathrm{K} 8$ ) were not obtained because the blood sample was not taken or was not sufficient for the analysis; free fatty acid data for males and data for females were analyzed using a Kruskal-Wallis test; all other data were analyzed by analysis of variance; values with different superscripts are significantly different from each other $(P<0.05)$.

Abbreviation: $n$, number of animals.

liver injury. Elevations in intestinal and plasma AP are observed in rats ingesting high concentrations of dietary lipid. ${ }^{47-50}$ Aspartate aminotransferase (AST) and alanine aminotransferase (ALT) activities were not affected by the dietary krill level, suggesting that the livers were functioning normally and that damage to the liver was not the cause of elevated plasma AP.

The reason for the increase in plasma free fatty acids in $\mathrm{K} 17$ and $\mathrm{K} 33$ males was unclear. It is possible that the decrease in stored glycogen in the liver may have caused a compensatory shift to catabolism of lipid, which would be expected to cause an increase in the plasma fatty acid level. Plasma urea and creatinine levels were also decreased in K33 animals, indicating that high dosages of the krill meal may have influenced protein intake or metabolism. The slight decrease in crude protein level of the $\mathrm{K} 33$ diet may be responsible for the changes in plasma urea and creatinine. The decrease in plasma bile acids levels with increasing krill inclusion may have been due to the sterol binding capacity of chitosan (a deacetylated metabolite of chitin), a characteristic this polysaccharide has in common with many other nonstarch polysaccharides. ${ }^{51}$ It could not be determined whether the pancreas or the kidneys were the source of the statistically significant but modest elevation of plasma amylase in K33 males.

The results of the hematological examination were unremarkable with the exception of a slight decrease in MCHC and an increase in the RDW of K33 animals. The cause for this is unknown, but it may be related to increased dietary fluorine. Inconsistent effects of fluorine on hematological variables have been reported in rats and humans. ${ }^{52,53}$ Reported findings include reduced RBC, HGB, HCT, and $\mathrm{MCHC}$. However, Khandare et $\mathrm{al}^{54}$ reported no adverse effects of fluorine on hematological variables in dogs. Likewise, Ersoy et a ${ }^{55}$ did not observe effects on any hematological variables in humans with endemic fluorosis. Few studies have reported on the effects of dietary krill meal on blood indices. Zaleska-Freljan and Cywińska ${ }^{56}$ examined the effect of different krill meals fed to laboratory rats. The mean values of HCT and HGB levels, and the mean corpuscular thickness and volume were lower in rats fed with krill carapace (shell) meal, but not in rats fed low chitin or standardized krill meal. The authors concluded that the changes observed were the result of excess fluorine in the diet.

There were no significant effects of krill meal on WBC parameters with the exception of a slight increase in neutrophils in K33 males. However, the average WBC in K17 and $\mathrm{K} 33$ males was higher than normal (approximately $\left.5.5-8.0 \times 10^{9} / \mathrm{L}\right) .{ }^{57} \mathrm{High}$ numbers of WBCs were observed in one male in the $\mathrm{K} 17$ group $\left(24.6 \times 10^{9} / \mathrm{L}\right)$ and in three males in the $\mathrm{K} 33$ group $\left(15.2-22.8 \times 10^{9} / \mathrm{L}\right)$, and the individual variation was reflected in the high standard deviation in these groups. The total WBC was not attributed to any cell type, and the differential cell counts did not differ between treatment groups or sex (data not shown). In one of the three high dosage group males exhibiting an increased WBC, mild inflammation was observed in rectal tissue, but in the other males, no specific cause for an inflammatory response was found.

\section{Histopathology}

Focal inflammatory changes in the liver and crystalline material in tubules of the kidneys occurred frequently in all groups of animals (including controls). The incidences of both of these findings increased in K17 and K33 animals. Although animals from the $\mathrm{K} 8$ group did not exhibit an increased incidence of focal inflammatory lesions in the liver, the frequency of finding crystalline material in the kidneys was slightly higher in K8 males than controls. The etiology and toxicological relevance of the focal inflammatory lesions in the liver are unclear based on the relative lack of changes in clinical chemistries related to the liver (AST and ALP) or other histopathological findings in the liver. Similarly, urea, creatinine, and creatine kinase were not increased in any groups of treated animals, which indicates that the observed increased frequency of crystalline material in the kidney 
tubules of the treated animals was not pathological in nature. As the finding of crystalline material in the tubules was a common finding in control animals consuming a fishmeal diet, it was concluded that mink may be predisposed to developing crystalline material in the kidneys regardless of diet.

\section{Conclusion}

The protein and energy value of Antarctic krill meal appeared to be comparable to that of the fishmeal used as a control diet, as indicated by feed intake and growth results. However, some effects that could be considered adverse were observed when krill meal was included in the diet at the medium concentration (K17). Effects noted at the K33 concentration were adverse and consistent with fluorosis. At the lowest inclusion level (K8), the only effects noted were an increased level of fluoride in bone (which had no effect on bone integrity) and a slight (nonsignificant) increase in the frequency of crystalline material in kidney tubules (which was not associated with clinical evidence of toxicity to the kidney). Therefore, it was concluded that $8 \%$ (based on dry matter) is the no observable adverse effect level of krill meal for growing mink.

\section{Acknowledgments}

We thank Arve Halstvedt, Torunn Osen, Marianne Brattberg, Elvis Mashingaidze Chikwati, and Ellen Hage for excellent technical assistance, and Signe Svindland and Line Johnsen for critical reading of the manuscript.

\section{Disclosure}

Aker BioMarine provided funding for the research project and publication of the manuscript. The authors report no other conflicts of interest in this work.

\section{References}

1. Pierce RW, Van der Veen J, Olcott HS. Proximate and lipids analyses of krill (Euphausia species) and red crab (Pleuroncodes planipes). Agric Food Chem. 1969;17:367-369.

2. Tou JC, Jaczynski J, Chen YC. Krill for human consumption: nutritional value and potential health benefits. Nutr Rev. 2007;65(2):63-77.

3. Hansen JØ, Penn M, Øverland M, et al. High inclusion of partially deshelled and whole krill meals in diets for Atlantic salmon (Salmo salar). Aquaculture. 2010;310:164-172.

4. Storebakken T. Krill as a potential feed source for salmonids. Aquaculture. 1988;70:193-205.

5. ASOC. Management of the Antarctic krill: ensuring the conservation of the Antarctic marine ecosystem. Presented by the Antarctic and Southern Ocean Coalition (ASOC). Report Number: SC-CCAMLR-XXIII/BG 2004:1-15.

6. EC. Fediol.eu. Directive 2002/32/EC of the European Parliament and of the Council of 7 May 2002 on Undesirable Substances in Animal Feed (OJ L 14, 30.5.2002, p. 10) [webpage on the Internet]. Bruxelles: Fediol; 2014. Available from: http://www.fediol.eu/data/Dir_2002_32_undesirable_ substances_in_feed_CONS_2006-10.pdf. Accessed July 10, 2014.
7. EC [webpage on the Internet]. Eur-lex.europa.eu. Fluorine. Commission Directive 2008/76/EC of 25 July 2008 amending Annex I to Directive 2002/32/EC of the European parliament and of the Council on undesirable substances in animal feed. Cited 2008. Available from: http://eur-lex.europa.eu/legal-content/ EN/TXT/PDF/?uri=CELEX: 32008L0076\&qid=1399497047743\& from=EN. Accessed June 18, 2014.

8. Boone RJ, Manthey M. The anatomical distribution of fluoride within various body segments and organs of Antarctic krill (Euphausia superba Dana). Archiv fuer Fischereiwissenschaft. 1983;341:81-85.

9. Zhang H, Jianming P, Xianhao C, Buying Z. Biogeochemistry research of fluoride in Antarctic Ocean I. The study of fluoride anomaly in Antarctic krill. Antarctic Res. 1993;4:55-61.

10. Soevik T, Braekkan OR. Fluoride in Antarctic krill (Euphausia superba) and Atlantic krill (Meganyctiphanes norvegica). J Fish Res Board Can. 1979;36:1414-1416.

11. IOM Fluoride. In: Dietary Reference Intakes for Calcium, Phosphorus, Magnesium Vitamin D, and Fluoride. National Academy of Sciences. Institute of Medicine. Washington, DC: National Academy Press; 2002:288-313.

12. Yoshitomi B, Aoki M, Oshima S. Effect of total replacement of dietary fish meal by low fluoride krill (Euphausia Superba) meal on growth performance of Rainbow trout (Oncorhynchus Mykiss) in fresh water. Aquaculture. 2007;266:219-225.

13. Christians O, Leinemann M. Investigations on the migration of fluoride from the shell into the muscle flesh of Antarctic krill (Euphausia superba Dana) in dependence of storage temperature and storage time. Arch Fish Wiss. 1983;34:87-95.

14. Adelung D, Buchholz F, Culik B, Keck A. Fluoride in tissues of krill Euphausia superba Dana and Meganyctiphanes norvegica $\mathrm{M}$. Sars in relation to the moult cycle. Polar Biol. 1987;7(1):43-50.

15. Tharanathan RN, Kittur FS. Chitin-The undisputed biomolecule of great potential. Crit Rev Food Sci Nutr. 2003;43(1):61-87.

16. Locarnini PS, Presley BJ. Trace element concentrations in Antarctic krill, Euphausia superba. Polar Biol. 1995;15:283-288.

17. Yamamoto Y, Honda K, Tatsukawa R. Heavy metal accumulation in Antarctic krill Euphausia superba. Proc NIPR Symp Polar Biol. 1987;1: 198-204.

18. Rainbow PS. Copper, cadmium and zinc concentrations in oceanic amphipod and euphausiid crustaceans, as a source of heavy metals to pelagic seabirds. Mar Biol. 1989;103:513-518.

19. Van Holde KE, Miller KI. Hemocyanins. Adv Protein Chem. 1995;47: $1-81$.

20. EC [webpage on the Internet]. Eur-lex.europa.eu. Copper. Commission Regulation (EC) No. 1334/2003 of 25 July 2003 amending the conditions for authorization of a number of additives in feedingstuff belonging to the group of trace elements. Cited 2003. Available from: http://eur-lex. europa.eu/legal-content/EN/TXT/PDF/?uri=CELEX:32003R1334\&qi $\mathrm{d}=1399497573924 \&$ from=EN. Accessed June 18, 2014.

21. Oehlenschläger J. Erster Nerzfütterungsversuch mit Krill. Infn. Fischw. 1979;26:48. Available from: http://aquaticcommons.org/6125/. Accessed July 10, 2014.

22. Oehlenschläger J. Weitere Ergebnisse der Nerzfütterung mit Krill. Infn. Fischw. 1980;27:162-165. Available from: http://aquaticcommons. org/6051/. Accessed July 10, 2014.

23. Calabrese EJ, Aulerich RJ, Padgett GA. Mink as a predictive model in toxicology. Drug Metab Rev. 1992;24(4):559-578.

24. Ahlstrøm Ø, Skrede A. Comparative nutrient digestibility in dogs, blue foxes, mink and rats. J Nutr. 1998;128(12):2676S-2677S.

25. Krogdahl Å, Ahlstrøm, Ø, Skrede A. Nutrient digestibility of commercial dog foods using mink as a model. J Nutr. 2004;134(8):2141S-2144S.

26. Clauss M, Kleffner H, Kienzle, E. Carnivorous mammals: nutrient digestibility and energy evaluation. Zoo Biol. 2010;29(6):687-704.

27. Krogdahl $\AA$, Ahlstrom Ø, Burri L, et al. Antarctic krill meal as an alternative protein source in pet foods evaluated in adult mink (Neovison vison). I. Digestibility of nutrients and effect on reproduction. Open Access Anim Physiol. In press 2015. 
28. Hansen N, Finne L, Skrede A, Tauson A. Energiforsyningen hos mink og ræv [Energy supply in mink and foxes]. NJF-report No. 63. DSR Forlag: Copenhagen; 2001.

29. Liu Z, Ning F, Du Z, et al. Modelling growth of five different colour types of mink. S Afr J Anim Sci. 2011;41(2):116-125.

30. Hansen JO, Shearer KD, Overland M, et al. Replacement of LT fish meal with a mixture of partially deshelled krill meal and pea protein concentrates in diets for Atlantic salmon (Salmo salar). Aquaculture. 2011;315:275-282.

31. Anugwa FO, Varel VH, Dickson JS, Pond WG, Krook LP. Effects of dietary fiber and protein concentration on growth, feed efficiency, visceral organ weights and large intestine microbial populations of swine. J Nutr. 1989;119:879-886.

32. Pond WG, Varel VH, Dickson JS, Haschek WM. Comparative responses of swine and rats to high-fiber or high-protein diets. J Anim Sci. 1989;67(3):716-723.

33. Zhao X, Jorgensen H, Eggum BO. The influence of dietary fibre on body-composition, visceral organ weight, digestibility and energybalance in rats housed in different thermal environments. Br J Nutr. 1995;73(5):687-699.

34. Starck JM. Phenotypic flexibility of the avian gizzard: rapid, reversible and repeated changes of organ size in response to changes in dietary fibre content. J Exp Biol. 1999;202(22):3171-3179.

35. Barbier O, Arreola-Mendoza L, Del Razo, LM. Molecular mechanisms of fluoride toxicity. Chem Biol Interact. 2010;188(2):319-333.

36. Dost FN, Knaus RM, Johnson DE, Wang CH. Fluoride impairment of glucose utilization: Nature of effect in rats during and after continuous NaF infusion. Appl Pharm. 1977;41:451-458.

37. Garcia-Montalvo EA, Reyes-Perez H, Del Razo LM. Fluoride exposure impairs glucose tolerance via decreased insulin expression and oxidative stress. Toxicology. 2009;263(2-3):75-83.

38. Stejskal SM, Aulerich RJ, Slanker MR, Braselton WE, Lehning EJ, Napolitano AC. Element concentrations in livers and kidneys of ranch mink. J Vet Diagn Invest. 1989;1(4):343-348.

39. EC. Opinion of the Scientific Committee for Animal Nutrition on the Use of Zinc in Feedingstuffs (Adopted on 14 March 2003). European Commission - Health and Consumer Protection Directorate-General. 2003. Available from: http://ec.europa.eu/food/fs/sc/scan/out120_ en.pdf. Accessed July 23, 2014.

40. Aulerich RJ, Napolitano AC, Bursian SJ, Olson BA, Hochstein JR. Chronic toxicity of dietary fluorine to mink. J Anim Sci. 1987;65(6): 1759-1767.

41. Schupe JL, Larsen AE, Olson AE. Effects of diets containing sodiumfluoride on mink. J Wildl Dis. 1987;23(4):606-613.
42. Cerklewski FL. Fluoride bioavailability - Nutritional and clinical aspects. Nutr Res. 1997;17:907-929.

43. Tenuta A, Alvarenga RCC. Reduction of the bioavailability of fluoride from Antarctic krill by calcium. Int J Food Sci Nutr. 1999;50: 297-302.

44. Vogel GL, Tenuta LM, Schumacher GE, Chow LC. No calcium-fluoridelike deposits detected in plaque shortly after a sodium fluoride mouth rinse. Caries Res. 2010;44(2):108-115.

45. Fernandes MS, Iano FG, Rocia V, et al. Alkaline phosphatase activity in plasma and liver of rats submitted to chronic exposure to fluoride. Braz Arch Biol Technol. 2011;54:1187-1192.

46. Lau KH, Baylink DJ. Molecular mechanism of action of fluoride on bone cells. J Bone Miner Res. 1998;13(11):1660-1667.

47. Grewal R, Mahmood A. Coordinated secretion of alkaline phosphatase into serum and intestine in fat-fed rats. Indian $J$ Gastroenterol. 2004;23(5):175-177.

48. Lina BA, Wolterbeek AP, Suwa Y, et al. Subchronic (13-week) oral toxicity study, preceded by an in utero exposure phase, with arachidonateenriched triglyceride oil (SUNTGA40S) in rats. Food Chem Toxicol. 2006;44(3):326-335.

49. Casterton PL, Curry LL, Lina BA, Wolterbeek AP, Kruger CL. 90-Day feeding and genotoxicity studies on a refined arachidonic acid-rich oil. Food Chem Toxicol. 2009;47(10):2407-2418.

50. Schmitt D, Tran N, Peach J, Bauter M, Marone P. Toxicologic evaluation of DHA-rich algal oil: genotoxicity, acute and subchronic toxicity in rats. Food Chem Toxicol. 2012;50(10):3567-3576.

51. Santas J, Espadaler J, Mancebo R, Rafecas M. Food selective in vivo effect of chitosan on fatty acid, neutral sterol and bile acid excretion: a longitudinal study. Food Chem. 2012;134(2):940-947.

52. Uslu B. Effects of fluoride on hemoglobin and hematocrit. Fluoride. $1981 ; 14: 38-41$.

53. Eren E, Ozturk M, Mumcu EF, Canatan D. Fluorosis and its hematological effects. Toxicol Ind Health. 2005;21(10):255-258.

54. Khandare AL, Kumar PU, Lakshmaiah N. Beneficial effect of tamarind ingestion on fluoride toxicity in dogs. Fluoride. 2000;33(1):33-38.

55. Ersoy IH, Alanoglu EG, Koroglu BK, et al. Effect of endemic fluorosis on hematological parameters. Biol Trace Elem Res. 2010;138(1-3): 22-27.

56. Zaleska-Freljan K, Cywińska L. The effect of different krill meals fed to laboratory rats on their blood indices. Comp Biochem Physiol A Comp Physiol. 1991;98(1):133-136.

57. Mustonen AM, Pyykonen T, Paakkonen T, et al. Adaptations to fasting in the American mink (Mustela vison): carbohydrate and lipid metabolism. Comp Biochem Physiol A Mol Integr Physiol. 2005;140(2):195-202.
Open Access Animal Physiology

\section{Publish your work in this journal}

Open Access Animal Physiology is an international, peer-reviewed, open access journal publishing original research, reports, reviews and commentaries on all areas of animal physiology. The manuscript management system is completely online and includes a very
Dovepress

quick and fair peer-review system. Visit http://www.dovepress.com/ testimonials.php to read real quotes from published authors. 